\title{
PENGARUH PROFITABILITAS, LEVERAGE, KEPEMILIKAN INSTITUSIONAL DAN CAPITAL INTENSITY TERHADAP PENGHINDARAN PAJAK DI BURSA EFEK INDONESIA
}

\section{The Effect Of Profitability, Leverage, Institutional Ownership And Capital Intensity On Tax Avoidance In Indonesia Stock Exchange}

\author{
Zainuddin \\ zainudin@unkhair.ac.id \\ Program Studi Akuntansi, Fakultas Ekonomi dan Bisnis, Universitas Khairun, \\ Ternate \\ J1. Jusup Abdurrahman, Kel. Gambesi, Kota Ternate, Maluku Utara \\ Anfas \\ anfas_st_mm@ut.ac.id \\ Jurusan Manajemen, Fakultas Ekonomi, Universitas Terbuka
}

\begin{abstract}
ABSTRAK
Penelitian ini dengan tujuan menganalisis pengaruh profitabilitas, leverage, kepemilikan institusional dan capital intensity terhadap penghindaran pajak pada perusahaan manufaktur yang terdaftar di Bursa Efek Indonesia tahun 2016-2018. Sampel dipilih berdasarkan teknik purposive sampling dengan total observasi sebanyak 63 perusahaan. Teknik analisis data yang digunakan adalah analisis regresi linear berganda dengan software SPSS for windows 25. Hasil penelitian menunjukkan bahwa variabel capital intensity berpengaruh signifikan terhadap penghindaran pajak. Sedangkan profitabilitas, leverage, dan kepemilikan institusional tidak berpengaruh terhadap penghindaran pajak.
\end{abstract}

Kata Kunci: Penghindaran Pajak, Profitabilitas, Leverage, Kepemilikan Institusional, Capital Intensity.

\begin{abstract}
This study aims to analyze the effect of profitability, leverage, institutional ownership and capital intensity on tax avoidance in companies listed on the Indonesia Stock Exchange in 2016-2018. The sample was selected based on purposive sampling technique with a total observation of 63 companies. The data analysis technique used is multiple linear regression analysis with SPSS for windows 25 software. The results showed that the capital intensity variable had a significant effect on tax avoidance. While profitability, leverage, and institutional ownership have no effect on tax avoidance.
\end{abstract}

Keywords: Tax Avoidance, Profitability, Leverage, Institutional Ownership, Capital Intensity. 


\section{PENDAHULUAN}

Setiap orang yang tergolong wajib pajak diharapkan melaksanakan kewajiban perpajakan nya dengan patuh. Akan tetapi, wajib pajak yang memiliki kewajiban pajak dengan nilai besar, tidak semua membayar pajaknya sesuai dengan yang harus dibayarkan. Akibatnya penerimaan negara dari sektor perpajakan berkurang dan secara langsung mengganggu keuangan negara yang disebabkan oleh ketidakpatuhan tersebut (Zainuddin, 2017). Seperti kasus pada tahun 2016, kebocoran dokumen yang terungkap dari pejabat publik dunia, politisi, dan kalangan superkaya tentang rahasia keuangan yang mengindikasikan perilaku tidak patut, tidak terbuka, dan tidak etis. Bocoran dokumen tersebut memiliki lebih dari 214.000 informasi perusahaan cangkang di 21 negara yang terdaftar suaka atau surga pajak (tax havens countries). International Consortium of Investigative Journalists (ICIJ) membuat laporan bernama Panama Papers menjelaskan bagaimana para politisi, kalangan superkaya dan pejabat meyembunyikan (melindungi) kekayaannya dengan mendirikan perusahaan cangkang (shell company) di negara-negara suaka atau surga pajak (Sudiarta, 2016).

Penghindaran pajak disebut pengurangan beban pajak yang harus dibayarnya dengan melakukan usaha-usaha. Melakukan tindakan memperkecil kewajiban pajak dalam koridor hukum adalah penghidaran pajak (Aumeerun, Jugurnath, \& Soondrum, 2016). Penghindaran pajak pada umumnya disebut sebagai teknikalitas, pengeksploitasian kompleksitas, dan celah dalam hukum perpajakan (De Lacy, 2015). Banyak kasus yang umumnya dilakukan oleh perusahaan besar terkait penghindaran pajak. Tidak saja di Indonesia tapi global. Seperti Ikea yang dikatakan tidak membayar pajak selama enam tahun lebih dari $€ 1$ miliar. Pada tahun 2014, menurut European Free Alliance/Greens, Ikea tidak membayar dan $€ 11,6$ juta di Inggris, $€ 24$ juta di Perancis, dan $€ 35$ juta pajak di Jerman. 
Perilaku penggelapan pajak adalah proses pengelakan pembayaran pajak yang dilakukan oleh wajib pajak secara legal untuk mengurangi jumlah pajak terutang dengan mencari kelemahan peraturan atau melanggar peraturan perpajakan (Halim, Bawono, \& Dara, 2020). Hubungan agensi merupakan perjanjian dimana orang lain dilibatkan pemilik sebagai agen untuk mengerjakan tindakan pelayanan atas nama mereka dalam pengambilan keputusan melalui pendelegasian wewenang (Jensen \& Meckling, 1976), sampai manager mempunyai posisi yang penting dalam pengambilan keputusan perusahaan (Desai \& Dharmapala, 2006). Masalah agensi dapat timbul dari manajer yang memiliki lebih banyak informasi dibandingkan pemegang saham.

Beberapa faktor yang dapat mempengaruhi penghindaran pajak antara lain profitabilitas, leverage, kepemilikan institusional dan capital intensity. Kabajeh, Nu'aimat, \& Dahmash (2012) menuturkan bahwa rasio profitabilitas adalah indikator untuk efisiensi keseluruhan perusahaan. Rasio profitabilitas mengukur kapasitas pendapatan perusahaan dan dianggap sebagai indikator untuk pertumbuhan, keberhasilan, dan kontrol. semakin tinggi profitabilitas maka akan semakin baik kinerja perusahaan tersebut. Meningkatnya laba suatu perusahaan maka menyebabkan beban pajak yang dibayarkan semakin tinggi. Penelitian Kraft (2014) menemukan bahwa meningkatnya profitabilitas perusahaan akan berdampak terhadap penurunan ETR (Effective Taxe Rate), yang berarti meningkatnya penghindaran pajak yang dilakukan, hasil sebaliknya ditemukan oleh penelitian Zarai et al. (2013) bahwa meningkatnya profitabilitas perusahaan akan berdampak terhadap peningkatan ETR, yang berarti semakin kecil penghindaran pajak yang dilakukan.

Selanjutnya, penghindaran pajak yang dilakukan oleh perusahaan terlihat dari kebijakan pendanaan yang diambil perusahaan. Salah satu kebijakan pendanaan adalah kebijakan leverage. Leverage merupakan suatu perbandingan yang mencerminkan besarnya utang yang digunakan untuk pembiayaan oleh perusahaan dalam menjalankan aktivitas operasinya (Koming \& Praditasari, 
2017). Meningkatnya perusahaan dalam penggunaan utang, mengakibatkan semakin banyak jumlah beban bunga yang dikeluarkan oleh perusahaan, sehingga dapat mengurangi laba sebelum kena pajak perusahaan yang dapat mengurangi besaran pajak yang nantinya harus dibayarkan oleh perusahaan.

Khurana and Moser (2011) menyatakan bahwa kepemilikan institusional yang ada di dalam perusahaan akan memainkan peran penting di dalam pemantauan, mendisiplinkan dan mempengaruhi manajer. Besar kecilnya konsentrasi kepemilikan institusional maka akan mempengaruhi kebijakan tindakan meminimalkan beban pajak oleh perusahaan.

Capital intensity merupakan salah satu faktor yang dapat mempengaruhi penghindaran pajak yang diukur dengan proporsi aset tetap yang dimiliki suatu perusahaan. Noor, Fadzillah, \& Mastuki (2010) dan Kraft (2014). Noor et al., (2010) menemukan bahwa capital intensity yang semakin tinggi, maka semakin rendah ETR. Semakin tinggi capital intensity pastinya menyebabkan semakin tinggi pula penghindaran pajak yang dilakukan perusahaan. Kraft (2014) mengatakan bahwa capital intensity tidak berpengaruh terhadap penghindaran pajak.

Penelitian ini dilakukan mengacu pada penelitian yang dilakukan oleh (Arianandini \& Ramantha, 2018). Kebaharuan dalam penelitian ini yaitu adanya penambahan variabel capital intensity sebagai salah satu bentuk keputusan keuangan oleh manajemen perusahaan dengan fokus meningkatkan profitabilitas perusahaan. Seberapa besar modal yang dibutuhkan perusahaan untuk menghasilkan pendapatan dicerminkan oleh Intensitas modal. Kraft (2014) menyebutkan bahwa perusahaan dengan modal yang intensif memiliki kesempatan yang lebih besar untuk perencanaan perpajakan atau strategi penghindaran pajak daripada perusahaan lain. Dari latar belakang di atas, peneliti tertarik melakukan penelitian dengan tujuan untuk menganalis pengaruh 
profitabilitas, leverage, kepemilikan institusional dan capital intensity terhadap tax avoidance pada perusahaan manufaktur di Bursa Efek Indonesia.

\section{METODE PENELITIAN}

\section{Objek dan Waktu Penelitian}

Objek penelitian ini yaitu perusahaan manufaktur yang listing di Bursa Efek Indonesia pada periode 2016-2018. Adapun waktu penelitian ini dilakukan selama satu bulan yaitu pada bulan Agustus 2020.

\section{Populasi dan Sampel}

Populasi dalam penelitian ini adalah seluruh perusahaan manufaktur yang listing di Bursa efek Indonesia pada periode 2016-2018. Sedangkan sampel dalam penelitian ini dipilih berdasarkan metode purposive sampling yaitu pengambilan sampel berdasarkan ketentuan tertentu yang sesuai dengan tujuan penelitian. Adapun kriteria yang ditetapkan adalah sebagai berikut:

1. Perusahaan Manufaktur yang tercatat dalam Bursa Efek Indonesia selama tahun penelitian yaitu tahun 2016-2018.

2. Laporan keuangan mempunyai tahun buku yang berakhir 31 Desember.

3. Perusahaan dengan nilai laba yang positif agar tidak mengakibatkan nilai Cash Effective Tax Rate (CETR) terdistorsi (Kurniasih \& Ratna Sari, 2013)

4. Perusahaan dengan nilai Cash ETR kurang dari satu agar tidak membuat masalah dalam estimasi model.

\section{Jenis dan Sumber Data}

Jenis data yang digunakan adalah data sekunder yang bersumber dari laporan keuangan publikasi perusahaan manufaktur yang listing di Bursa Efek Indonesia periode 2016-2018.

\section{Metode Pengumpulan Data}

Metode pengumpulan data yang digunakan adalah dokumentasi. Menurut Arikunto (2014: 201) metode dokumentasi adalah objek yang diperhatikan (ditatap) dalam memperoleh informasi berupa tiga macam sumber, yaitu tulisan 
(paper), tempat (place), dan kertas atau orang (people). Dokumen yang diperlukan dalam penelitian ini adalah laporan keuangan perusahaan manufaktur yang listing di Bursa Efek Indonesia periode 2016-2018 yang diakses melalui www.idx.co.id dan situs web perusahaan terkait.

\section{Metode Analisis Data}

Metode data dalam penelitian ini menggunakan metode analisis Regresi Linear Berganda (Multiple Regression Linear). Adapun Regresi Linear Berganda dapat dirumuskan sebagai berikut :

\section{CETR $=\alpha+\beta 1$ ROA $+\beta 2$ LEV $+\beta 3$ INSTI $+\beta 4$ CINT $+\epsilon$}

Dimana :

CETR : Penghindaran Pajak (Tax Avoidance)

a : Konstanta

b : Koefisien Regresi

ROA : Profitabilitas

LEV : Leverage

INSTI : Kepemilikan Institusional

CINT : Capital Intensity

e : Error

\section{Definisi Operasional Variabel Penelitian}

\section{Penghindaran Pajak (Tax Avoidance)}

Penghindaran pajak dalam penelitian ini diukur menggunakan ETR (effectives tax rate). Menurut Frank, Lynch and Rego (2009) penghindaran pajak merupakan upaya manajemen dalam mengelola penghasilan kena pajak berdasarkan serangkaian aktivitas perencanaan pajak yang legal, ilegal maupun yang berdiri diantaranya. Variabel penghindaran pajak dihitung dengan Current ETR yang merupakan penghitungan yang mengakomodasikan pajak yang dibayarkan saat ini oleh perusahaan. Nilai Current ETR yang rendah akan 
berdampak pada peningkatan penghindaran pajak. Current ETR dalam penelitian dihitung dengan rumus yang dikembangkan oleh (Hanlon \& Heitzman, 2010).

$$
\text { Current ETR }=\frac{\text { Current Tax Expanse }}{\text { Pre Tax Income }}
$$

Keterangan:

Current ETR

Current Tax Expense

Pre tax Income

: Effective tax rate berdasarkan jumlah pajak yang dibayarkan perusahaan pada tahun berjalan.

: Jumlah beban pajak yang dibayarkan perusahaan pada tahun tersebut berdasarkan laporan keuangan perusahaan.

: Pendapatan sebelum pajak untuk perusahaan pada tahun tersebut berdasarkan laporan keuangan perusahaan,

\section{Profitabilitas}

Rasio yang digunakan dalam mengukur profitabilitas dalam penelitian ini yaitu return on assets (ROA), dimana pengukuran ini digunakan untuk mengetahui kemampuan perusahaan dalam memanfaatkan asetnya dalam memperoleh keuntungan. Kabajeh, Nu'aimat and Dahmash (2012) menyebutkan bahwa rasio profitabilitas merupakan indikator untuk efisiensi keseluruhan perusahaan, yang mana biasanya digunakan sebagai ukuran untuk laba yang dihasilkan oleh perusahaan selama periode waktu berdasarkan tingkat penjualan, aset, modal yang digunakan, kekayaan bersih dan laba per saham. Rerturn on assets (ROA) dalam penelitian ini dihitung dengan membandingkan laba bersih dengan total aset yang dimiliki perusahaan (Damayanti \& Susanto, 2016; Kabajeh et al., 2012; Zarai et al., 2013) yang dapat dirumuskan sebagai berikut:

$$
R O A=\frac{\text { Laba bersih setelah pajak }}{\text { Total Aset }}
$$




\section{Leverage}

Leverage adalah salah satu rasio keuangan yang menggambarkan hubungan antara hutang perusahaan terhadap modal maupun asset perusahaan. Rasio leverage menggambarkan sumber dana operasi yang digunakan oleh perusahaan. Rasio leverage juga menunjukkan risiko yang dihadapi perusahaan. Leverage diukur dengan total debt to equity ratio dengan rumus sebagai berikut (Arianandini \& Ramantha, 2018):

$$
D E R=\frac{\text { Total Liabilitas }}{\text { Total Ekuitas }}
$$

\section{Kepemilikan Institusional}

Kepemilikan institusional adalah kepemilikan saham perusahaan yang dimiliki oleh institusi atau lembaga seperti perusahaan asuransi, bank, perusahaan investasi dan kepemilikan institusi lain. Kepemilikan institusional dinyatakan dalam presentase (\%) yang diukur dengan cara membandingkan jumlah lembar saham yang dimiliki oleh investor institusional dibagi dengan jumlah lembar saham yang beredar.

$$
I N S T=\frac{\text { Jumlah saham yang dimiliki investor institusi }}{\text { Total saham yang beredar }}
$$

\section{Capital Intensity}

Capital intensity merupakan sejumlah dana yang ditanamkan untuk mendapatkan output tambahan. Semakin besar modal digunakan untuk menghasilkan unit yang sama, dapat dikatakan bahwa semakin intens modal perusahaan (Shaheen \& Ali Malik, 2012). Biasanya , capital intensity dikaitkan dengan satuan modal yang dimiliki oleh perusahaan berupa aset tetap, sehingga rasio intensitas aset tetap diukur dengan berapa proporsi aset tetap dari total aset yang dimiliki perusahaan (Kraft, 2014; Richardson, 2006), yang dapat dirumuskan sebagai berikut:

$$
\text { Capital Intensity }=\text { Total Fixed Aset } / \text { Total Aset }
$$




\section{HASIL DAN PEMBAHASAN}

\section{Hasil Penelitian}

Penelitian ini dimaksudkan untuk menguji pengaruh profitabilitas, leverage, kepemilikan institusional dan capital intensity terhadap tax avoidance. Hasil pengujian dengan menggunakan metode analisis regresi berganda tampak pada tabel berikut:

Tabel 1. Hasil Analisis Regresi Berganda

\begin{tabular}{|c|c|c|c|c|c|c|}
\hline & \multirow[t]{2}{*}{ Model } & \multicolumn{2}{|c|}{$\begin{array}{c}\text { Unstandardized } \\
\text { Coefficients }\end{array}$} & \multirow{2}{*}{$\begin{array}{c}\text { Standardized } \\
\text { Coefficients } \\
\text { Beta }\end{array}$} & \multirow[t]{2}{*}{$\mathrm{t}$} & \multirow[t]{2}{*}{ Sig. } \\
\hline & & $\mathrm{B}$ & Std. Error & & & \\
\hline \multirow[t]{9}{*}{1} & (Constant) & 0,310 & 0,049 & & 6,308 & 0,000 \\
\hline & ROA & $-0,101$ & 0,225 & $-0,057$ & $-0,449$ & 0,655 \\
\hline & LEV & 0,020 & 0,011 & 0,222 & 1,754 & 0,085 \\
\hline & INSTI & 0,021 & 0,041 & 0,061 & 0,522 & 0,604 \\
\hline & CINT & $-0,188$ & 0,063 & $-0,372$ & $-3,001$ & 0,004 \\
\hline & R Square & 0.230 & & & & \\
\hline & Adj R Square & 0.177 & & & & \\
\hline & F Change & 4.333 & & & & \\
\hline & Sig F & 0.004 & & & & \\
\hline
\end{tabular}

Dependent Variable: Tax avoidance

Sumber : data sekunder diolah.

Dari tabel 1, tampak hasil pengujian determinan, pengujian secara simultan dan parsial yang dijabarkan lebih lengkap sebagai berikut:

\section{Uji Determinasi}

Koefisien determinasi $\left(\mathrm{R}^{2}\right)$ dipakai untuk mengukur seberapa jauh kemampuan model dalam menjelasakan variasi variabel dependennya. Nilai Koefisien determinasi yang mendekati satu berarti variabel-variabel independennya mampu menjelaskan hampir semua informasi yang dibutuhkan dalam memprediksi variabel dependen (Ghozali, 2016: 41). Hasil perhitungan Koefisien Determinasi penelitian ini terlihat nilai koefisien determinasi $\left(\mathrm{R}^{2}\right)$ sebesar 0,230. Dengan kata lain hal ini menunjukkan bahwa besar presentase 
variasi Tax avoidance yang bisa dijelaskan oleh keempat variabel bebas yaitu profitabilitas, leverage, kepemilikan institusional dan capital intensity sebesar $23 \%$, sedangkan sisanya sebesar $77 \%$ dijelaskan oleh variabel-variabel lain diluar model.

\section{Uji Simultan (Uji F)}

Uji simultan pada dasarnya menunjukkan apakah semua variabel independen yang dimasukkan dalam model mempunyai pengaruh secara bersamasama terhadap variabel dependennya. Dari hasil uji regresi dengan SPSS nampak bahwa pengaruh secara bersama-sama variabel profitabilitas, leverage, kepemilikan institusional dan capital intensity terhadap Tax avoidance diperoleh nilai $F$ sebesar 4,333 dan nilai signifikansi sebesar 0,004. Melihat nilai signifikansi lebih kecil dari 5\% maka secara simlutan terdapat pengaruh yang signifikan antara variabel independen terhadap Tax avoidance.

\section{Uji Parsial (Uji t)}

Uji t statistik dimaksudkan untuk mengetahui apakah terdapat pengaruh secara parsial (individu) dari variabel-variabel independen terhadap Tax avoidance. Hasil pengujian secara parsial dapat dijabarkan dengan persamaan regresi linier berganda sebagai berikut:

\section{$C E T R=0,310-0,101$ ROA +0.020 LEV + 0.021 INSTI -0.188 CINT + e}

Hasil pengujian hipotesis dijelaskan sebagai berikut:

1. Variabel profitabilitas menunjukkan nilai koefisien regresi sebesar $-0,101$ dengan probabilitas variabel sebesar 0,655 di atas signifikasi 0,05 (5 persen). Hal ini dapat diartikan bahwa profitabilitas tidak berpengaruh terhadap tax avoidance. Dengan demikian hipotesis 1 yang menyatakan profitabilitas berpengaruh terhadap tax avoidance ditolak.

2. Variabel leverage menunjukkan nilai koefisien regresi sebesar 0,020 dengan probabilitas variabel sebesar 0,085 di atas signifikasi 0,05 (5 persen). Hal ini dapat diartikan bahwa leverage tidak berpengaruh terhadap tax avoidance. 
Dengan demikian hipotesis 2 yang menyatakan leverage berpengaruh terhadap tax avoidance ditolak.

3. Variabel kepemilikan institusional menunjukkan nilai koefisien regresi sebesar 0,021 dengan probabilitas variabel sebesar 0,604 di atas signifikasi 0,05 (5 persen). Hal ini dapat diartikan bahwa kepemilikan institusional berpengaruh terhadap tax avoidance. Dengan demikian hipotesis 3 yang menyatakan kepemilikan institusional berpengaruh terhadap tax avoidance ditolak.

4. Variabel capital intensity menunjukkan nilai koefisien regresi sebesar 0,188 dengan probabilitas variabel sebesar 0,004 di bawah signifikasi 0,05 (5 persen). Hal ini dapat diartikan bahwa capital intensity berpengaruh terhadap tax avoidance. Dengan demikian hipotesis 4 yang menyatakan capital intensity berpengaruh terhadap tax avoidance diterima.

\section{Pembahasan}

\section{Profitabilitas berpengaruh terhadap Tax avoidance}

Hasil penelitian menunjukkan bahwa profitabilitas tidak memiliki pengaruh terhadap tax avoidance. ROA yang dalam penelitian ini merupakan proksi dari profitabilitas merupakan faktor penting dalam pengenaan pajak penghasilan bagi perusahaan. Nilai ROA yang tinggi mengindikasikan perencanaan pajak yang matang sehingga menghasilkan pajak yang optimal dan cenderung aktivitas tax avoidance akan mengalami penurunan. Perusahaan yang memiliki efisiensi tinggi dalam kegiatan operasionalnya akan mendapatkan tax subsidy yang berupa tarif pajak efektif lebih rendah dibandingkan dengan perusahaan yang beroperasi dengan efisiensi rendah. Semakin tinggi ROA tidak mempengaruhi tax avoidance. Hasil penelitian ini konsisten dengan hasil penelitian yang dilakukan oleh (Meilinda dan Cahyonowati, 2013) yang menyatakan bahwa ROA tidak berpengaruh terhadap tax avoidance. 


\section{Leverage berpengaruh terhadap Tax avoidance}

Hasil penelitian dengan menggunakan regresi linier berganda memperoleh hasil bahwa leverage tidak berpengaruh terhadap penghindaran pajak. Leverage adalah salah satu rasio yang menggambarkan hubungan antara hutang perusahaaan terhadap modal maupun aset perusahaan. Semakin tinggi nilai leverage, maka beban bunga perusahaan akan mengalami peningkatan sehingga mampu mempengaruhi beban pajak perusahaan Perusahaan yang memiliki kewajiban perpajakan yang tinggi akan memilih untuk berhutang agar mengurangi beban pajaknya (Ozkan, 2001). Pasal 6 ayat (1) huruf a UU Nomor 36 tahun 2008 menyebutkan bahwa bunga hutang adalah beban yang dapat dikurangkan untuk tujuan perhitungan perpajakan. Perusahaan yang memilih kebijakan leverage akan mendapatkan insentif pajak yang memanfaatkan beban bunga untuk memperkecil beban pajaknya. Sehingga perusahaan yang memiliki nilai leverage tinggi cenderung melakukan tindakan tax avoidance sebagai akibat dari insentif pajak atas beban bunga yang diterima perusahaan untuk meminimalkan beban pajaknya. Sesuai dengan teori stakeholder yang menuntut manajer untuk mempertimbangkan kepentingan stakeholder sehingga kinerjanya dinilai baik.

Hasil penelitian ini mendukung hasil temuan (Cahyono, Andini, \& Raharjo, 2016); (Darmawan \& Sukartha, 2014), (Putra \& Merkusiwati, 2016), (Agusti, 2013), (Hidayat, 2018), yang menyatakan bahwa leverage DER tidak berpengaruh terhadap tax avoidance.

\section{Kepemilikan institusional berpengaruh terhadap Tax avoidance.}

Hasil penelitian dengan menggunakan regresi linier berganda memperoleh hasil bahwa kepemilikan institusional tidak berpengaruh terhadap Tax avoidance. Kepemilikan institusional pada penelitian ini menunjukkan bahwa tidak berpengaruh signifikan pada penghindaran pajak. Keberadaan struktur kepemilikan institusional tersebut mengindikasikan adanya tekanan dari pihak institusional kepada manajemen perusahaan untuk melakukan kebijakan pajak agresif untuk memaksimalkan perolehan laba untuk investor institusional. Perusahaan memiliki tanggung jawab kepada pemegang saham, maka pemilik 
institusional memiliki insentif untuk memastikan bahwa manajemen perusahaan membuat keputusan yang akan memaksimalkan kesejahteraan pemegang saham. Pada pengungkapan suka rela menemukan bahwa perusahaan dengan kepemilikan institusional yang lebih besar lebih memungkinkan untuk mengeluarkan, meramalkan dan memperkirakan sesuatu lebih spesifik, akurat dan optimis (Khurana \& Moser, 2011).

Menurut (Jensen \& Meckling, 1976) dalam (Sujoko \& Yuniati, 2016) memaparkan bahwa hasil temuan penelitian ini tidak mendukung agency theory, karena berdasarkan agency theory terdapat pemisahan antara pemilik dengan pengelola, akan tetapi hasil penelitian menunjukkan peranan pendiri perusahaan sangat dominan dalam menentukan kebijakan perusahaan. Kepemilikan institusional yang bertindak sebagai pihak yang memonitor perusahaan belum tentu mampu memberikan kontrol yang baik terhadap tindakan manajemen atas oportunistiknya dalam melakukan praktik tax avoidance. Hal ini dapat disebabkan oleh kualitas sumber daya dari pemilik institusional yang masih kurang. Pemegang saham institusi tidak menjalankan wewenangnya dengan benar dalam mengawasi serta mengontrol keputusan yang diambil oleh manajer sehingga tax avoidance tetap terjadi.

Selain alasan di atas, beberapa hal yang diduga menjadi alasan mengapa besarnya kepemilikan institusional tidak berpengaruh terhadap tax avoidance. Pertama, kepemilikan institusional merupakan proporsi kepemilikan saham oleh institusi diluar kepemilikan saham dewan komisaris perusahaan, dimana pemilik institusional ikut serta dalam pengawasan dan pengelolaan perusahaan namun demikian bisa saja pemilik institusional mempercayakan pengawasan dan pengelolaan perusahaan kepada dewan komisaris karena itu merupakan tugas mereka sehingga ada atau tidaknya kepemilikan institusional tetap saja tax avoidance terjadi.

Kedua, kepemilikan institusional berpikir untuk memaksimalkan kesejahteraan mereka terutama pada keuntungan atau laba yang akan mereka peroleh pada perusahaan sehingga semua kegiatan yang akan merugikan 
perusahaan termasuk adanya pajak agresif yang akan dilakukan perusahaan, jika kegiatan itu menguntungkan bagi kesejahteraan pemilik instituional maka mereka akan tetap mendukung setiap kegiatan atau kebijakan yang akan dilakukan perusahaan sehingga besar atau kecilnya kepemilikan institusional tidak akan mempengaruhi tindakan tax avoidance.

Ketiga, pemilik institusional kurang peduli dengan citra perusahaan asalkan itu bisa memaksimalkan kesejahteraan mereka walaupun adanya perilaku manajer dalam hal mengambil suatu keputusan terutama dalam hal pajak yaitu tindakan tax avoidance. Penelitian ini mendukung penelitian (Arianandini \& Ramantha, 2018) dan (Annisa, 2012) yang menyatakan kepemilikan institusional tidak berpengaruh terhadap tax avoidance.

\section{Capital Intensity berpengaruh terhadap Tax avoidance.}

Hasil penelitian dengan menggunakan regresi linier berganda memperoleh hasil bahwa capital intensity berpengaruh terhadap Tax avoidance. Rasio capital intensity berdasarkan pada jumlah modal perusahaan yang tertanam dalam bentuk aktiva tetap dan persediaan yang dimiliki perusahaan. Faktor ini juga dapat menggambarkan seberapa besar perusahaan menginvestasikan asetnya dalam bentuk aset tetap dan persediaan. Kepemilikan aset tetap oleh perusahaaan akan memunculkan keberadaan biaya depresiasi setiap tahunnya yang mana dapat dimanfaatkan dalam mengurangi pembayaran pajak. Teori agensi menyatakan bahwa dalam perusahaan terdapat perbedaan kepentingan antara pemilik saham (principal) dengan manajemen (agen) yang bertindak sesuai kepentingan diri mereka sendiri. Manajemen memiliki kepentingan berupa meningkatkan kinerja perusahaan untuk mendapatkan kompensasi yang diinginkan. Sehubungan dengan hal tersebut, manajemen dapat memanfaatkan penyusutan aset untuk menekan beban pajak perusahaan. Manajer akan menginvestasikan dana perusahaan yang menganggur ke dalam bentuk aset tetap dengan tujuan memanfaatkan penyusutannya sebagai pengurang beban pajak. Sehingga untuk meningkatkan kinerja perusahaan serta mencapai kompensasi kinerjanya, maka manajemen akan melakukan tax avoidance berupa pengurangan beban pajak. 
Hal ini sesuai dengan penelitian yang dilakukan oleh (Budhi \& Dharma, 2017) yang menemukan adanya pengaruh signifikan atas capital intensity ratio terhadap penghindaran pajak. Sehingga perusahaan dengan tingkat aset tetap tinggi memiliki beban pajak yang rendah dikarenakan pemotongan pajak oleh adanya biaya depresiasi setiap tahun. Oleh sebab itu, tingginya capital intensity ratio juga menunjukkan menurunkan kemungkinan perusahaan dalam melakukan tindak penghindaran pajak sebagai akibat dari munculnya biaya depresiasi. Hal ini berbeda dengan temuan (Putra \& Merkusiwati, 2016) yang tidak menemukan adanya pengaruh atas capital intensity ratio terhadap tax avoidance.

\section{KESIMPULAN DAN SARAN}

Berdasarkan hasil penelitian yang telah dilakukan dapat ditarik kesimpulan bahwa profitabilitas tidak berpengaruh terhadap tax avoidance, leverage tidak berpengaruh terhadap tax avoidance, kepemilikan institusional tidak berpengaruh terhadap tax avoidance, dan capital Intensity berpengaruh negatif dan signifikan terhadap tax avoidance. Sejumlah keterbatasan yang ada dalam analisis ini, yang memungkinkan dapat menimbulkan gangguan pada hasil analisis ini diantaranya keterbatasan sampel penelitian dari sektor manufaktur, sehingga hasil penelitian yang diperoleh hanya mencerminkan tax avoidance pada perusahaan manufaktur, selain itu keterbatasan periode tahun pengamatan yang digunakan dalam penelitian ini hanya dilakukan selama 3 tahun.

Penelitian selanjutnya diharapkan dapat memperluas populasi dan sampel penelitian selain perusahaan yang bergerak di industri sektor manufaktur, saran ini bertujuan agar pengembangan ilmu di bidang tax avoidance dapat lebih luas jangkauannya dan dapat digeneralisasi, selain itu dapat menambah periode tahun pengamatan agar hasil dari penelitian tersebut dapat menjadi lebih akurat dan cakupannya lebih luas serta bertujuan untuk memperoleh hasil yang lebih bervariatif yang dapat menggambarkan variabel apa saja yang berpengaruh dan tidak berpengaruh terhadap tax avoidance. 


\section{DAFTAR PUSTAKA}

Agusti, W. Y. 2013. Pengaruh Profitabilitas, Leverage, dan Corporate Governance (Studi Empiris Pada Perusahaan Manufaktur yang Terdaftar di BEI tahu 2009-2012. Jurnal Simposium Nasional Akuntansi, 4(2), 1-32.

Annisa, N. A. 2012. Pengaruh Corporate Governance Terhadap Tax Avoidance. Jurnal Akuntansi Dan Auditing, 8(2), 123-136.

Arianandini, P. W., \& Ramantha, I. W. 2018. Pengaruh Profitabilitas, Leverage, dan Kepemilikan Institusional Pada Tax Avoidance. E-Jurnal Akuntansi, 22, 2088. https://doi.org/10.24843/eja.2018.v22.103.p17

Arikunto, S. 2014. Prosedur Penelitian Suatu Pendekatan Praktik. Jakarta: Rineka Cipta.

Aumeerun, B., Jugurnath, B., \& Soondrum, H. 2016. Tax evasion: Empirical evidence from sub-Saharan Africa. Journal of Accounting and Taxation, 8(7), 70-80. https://doi.org/10.5897/jat2016.0225

Budhi, N., \& Dharma, S. 2017. Pengaruh Corporate Social Responsility dan Capital Intensity Terhadap Tax Avoidance. E-Jurnal Akuntansi Universitas Udayana, 18(1), 529-556.

Cahyono, D. D., Andini, R., \& Raharjo, K. 2016. Pengaruh Komite Audit, Kepemilikan Institusional, Dewan Komisaris, Ukuran Perusahaan (Size), Leverage (DER) dan Profitabilitas (ROA) terhadap Tindakan Penghindaran Pajak (Tax Avoidance) PAda Perusahaan Perbankan yang listing BEI Periode Tahun 2011-2013. Journal Of Accounting, 2(2). Retrieved from https://www.infodesign.org.br/infodesign/article/view/355\%0Ahttp://www.a bergo.org.br/revista/index.php/ae/article/view/731\%0Ahttp://www.abergo.or g.br/revista/index.php/ae/article/view/269\%0Ahttp://www.abergo.org.br/revi sta/index.php/ae/article/view/106

Damayanti, F., \& Susanto, T. 2016. Pengaruh Komite Audit, Kualitas Audit, Kepemilikan Institusional, Risiko Perusahaan Dan Return on Assets Terhadap Tax Avoidance. Esensi, 5(2), 187-206. https://doi.org/10.15408/ess.v5i2.2341

Darmawan, I., \& Sukartha, I. 2014. Pengaruh Penerapan Corporate Governance, Leverage, Roa, Dan Ukuran Perusahaan Pada Penghindaran Pajak. E-Jurnal Akuntansi, 9(1), 143-161.

De Lacy, G. N. 2015. Peter J Dowling, Marion Festing and Allen D Engle Sr (2013) International human resource management, 6th edition. Cengage Learning, London. ISBN-13: 978140807574 6; 400 pages; \$117.75 (pbk). Asia Pacific Journal of Human Resources, 53(3), 386-388. https://doi.org/10.1111/1744-7941.12050 
Desai, M. A., \& Dharmapala, D. 2006. Corporate tax avoidance and high-powered incentives. Journal of Financial Economics, 79(1), 145-179. https://doi.org/10.1016/j.jfineco.2005.02.002

Frank, M. margaret, Lynch, L. J., \& Rego, S. O. 2009. Tax Reporting Aggressiveness and Its Relation Financial Reporting University of Virginia. Accounting Review, 84(2), 467-496.

Ghozali, I. 2016. Aplikasi Analisis Multivariate dengan Program IBM SPSS 23.

Godfrey, J., Hodgson, A., Tarca, A., Hamilton, J., \& Holmes, S. 2010. Accounting Theory, 7th Edition. In McGraw Hill. New York.

Halim, A., Bawono, I. R., \& Dara, A. 2020. Perpajakan (Konsep, Aplikasi, Contoh, dan Studi Kasus) (3rd ed.). Jakarta: Salemba Empat.

Hanlon, M., \& Heitzman, S. 2010. A review of tax research. Journal of Accounting and Economics, 50(2-3), 127-178. https://doi.org/10.1016/j.jacceco.2010.09.002

Hidayat, W. W. 2018. Pengaruh Profitabilitas, Leverage Dan Pertumbuhan Penjualan Terhadap Penghindaran Pajak: Studi Kasus Perusahaan Manufaktur Di Indonesia. Jurnal Riset Manajemen Dan Bisnis, 3(1), 19-26.

Jensen, M. C., \& Meckling, W. H. 1976). Theory of The Firm: Managerial Behavior, Agency Cost and Ownership Structure. Journal of Financial Economic, 3, 305-360. https://doi.org/10.1177/0018726718812602

Kabajeh, M. A. M., Nu'aimat, S. M. A., \& Dahmash, F. N. 2012. The Relationship between the ROA, ROE and ROI Ratios with Jordanian Insurance Public Companies Market Share Prices. International Journal Of Humanities and Social Science, 2(11).

Khurana, I. K., \& Moser, W. J. 2011. Institutional Ownership and Tax Aggressiveness. SSRN Electronic Journal, (573), 0-42. https://doi.org/10.2139/ssrn.1464106

Koming, N., \& Praditasari, A. 2017. Pengaruh Good Corporate Governance, Ukuran Perusahaan, Leverage Dan Profitabilitas Pada Tax Avoidance. EJurnal Akuntansi, 2017(1), 1229-1258.

Kraft, A. 2014. What Really Affects German Firms' Effective Tax Rate? International Journal of Financial Research, 5(3), 1-19. https://doi.org/10.5430/ijfr.v5n3p1

Kurniasih, T., \& Ratna Sari, M. 2013. Pengaruh Return on Assets, Leverage, Corporate Governance, Ukuran Perusahaan Dan Kompensasi Rugi Fiskal Pada Tax Avoidance. Buletin Studi Ekonomi, 18(1), 58-66. 
Meilinda, M., \& Cahyonowati, N. 2013. Pengaruh Corporate Governance. Diponegoro Journal Of Accounting, 2, 1-107.

Noor, R. M., Fadzillah, N. S. M., \& Mastuki, N. 2010. Corporate Tax Planning: A Study On Corporate Effective Tax Rates of Malaysian Listed Companies. International Journal of Trade, Economics and Finance, 1(2), 189-193. https://doi.org/10.7763/ijtef.2010.v1.34

Ozkan, A. 2001. Determinants of capital structure and adjustment to long run target: Evidence from UK company panel data. Journal of Business Finance and Accounting, 28(1-2), 175-198. https://doi.org/10.1111/1468-5957.00370

Putra, I. G. L. N. D. C., \& Merkusiwati, N. K. L. A. 2016. Pengaruh Komisaris Independen, Leverage, Size Dan Capital Intensity Ratio Pada Tax Avoidance. E-Jurnal Akuntansi Universitas Udayana, 17(1), 690-714.

Richardson, G. 2006. Determinants of tax evasion: A cross-country investigation. Journal of International Accounting, Auditing and Taxation, 15(2), 150-169. https://doi.org/10.1016/j.intaccaudtax.2006.08.005

Shaheen, S., \& Ali Malik, Q. 2012. The Impact of Capital Intensity, Size of Firm And Profitability on Debt Financing In Textile Industry of Pakistan Sadia Shaheen ( Principal Author ) Foundation University Islamabad Qaisar Ali Malik ( Corresponding Author ) Assistant Professor , Foundatio. Interdisciplinary Journal of Contemporary Research in Business, 3(10), 1061-1066.

Sudiarta, I. W. 2016. Panama Papers dan Praktik Penghindaran Pajak. Retrieved from CNN Indonesia website: https://www.cnnindonesia.com/ekonomi/20160412112445-79-

123307/panama-papers-dan-praktik-penghindaran-pajak

Sujoko, S., \& Yuniati, R. 2016. Analisis Perilaku "Striving For Superiority" Pada Siswa Yang Tidak Lulus Ujian Nasional. Intuisi Jurnal Ilmiah Psikologi, 8(2), 1-15. $\quad$ Retrieved from http://journal.unnes.ac.id/nju/index.php/INTUISI\%0A

Zainuddin, Z. 2017. Pengetahuan Dan Pemahaman Aturan Perpajakan, Kualitas Pelayanan Dan Persepsi Atas Efektifitas Sistem Perpajakan Terhadap Kemauan Membayar Pajak Dengan Kesadaran Membayar Pajak Sebagai Variabel Intervening. Jurnal Riset Akuntansi Terpadu. https://doi.org/10.35448/jrat.v10i2.4252

Zarai, Z., Boujelbene, E., Ben Salem, N., Gargouri, Y., \& Sayari, A. 2013. Antioxidant and antimicrobial activities of various solvent extracts, piperine and piperic acid from Piper nigrum. LWT - Food Science and Technology, 50(2), 634-641. https://doi.org/10.1016/j.lwt.2012.07.036 